\title{
Use of Radiotracking in France for Recent Stu- dies Concerning the E.D.F. Fishways Program
}

\author{
F. Travade(1), P. Bomassi(2), J.M. Bach(2), C. Brugel(2), P. Stein- \\ bach $^{(3)}$, J.F. Luquet(3), G. Pustelnik ${ }^{(4)}$.
}

(1) Electricité de France - Direction des Etudes et Recherches

6, quai Watier 78400 Chatou - France

(2) Conseil Supérieur de la Pêche

84, Avenue du Puy de Dôme 63000 Clermont-Ferrand - France

(3) Conseil Supérieur de la Pêche

112, Faubourg de la Cueille 86000 Poitiers - France

(4) Conseil Supérieur de la Pêche

La Vigne basse 24200 Sallat - France

Summary. - Radiotracking studies have been carried out since 1985 on three species of migratory fish - Atlantic salmon (Salmo salar), sea trout (Salmo trutta trutta), shad (Alosa alosa) - in relation to surveys carried out before and after the construction of fishways on Electricité de France dams.

Three sites were investigated:

- Poutes-Monistrol hydropower project on the Allier river : determination of the possibility for salmon to reach the new fishlift entry located at the Poutes dam; the effect of Monistrol powerhouse discharge on migration was particularly analysed,

- $S^{t}$-Laurent-des-eaux weir on the Loire river : determination of the projected fishway's characteristics for shad,

- Mauzac dam on the Dordogne river : determination of the attractivity, for shad and sea trout, of a new fishway located close to the powerhouse.

American radiotracking equipment was used (Advanced Telemetry System and Smith Root) with frequency ranges $40-41 \mathrm{MHz}$ and $48-49 \mathrm{MHz}$.

Fishes were tagged with transmitters of various sizes implanted in the stomach. A total of 28 shad, 43 salmon and 18 sea trout were tagged.

Various techniques of tracking have been employed according to each site and fish species :

- for manual tracking (by foot, car, boat or plane), we employed various antennas : loop, adcock, whip or underwater. Precise location was made by biangulation or triangulation with receivers or by use of underwater antennas;

- automatic tracking with graphic recorders was used for continuous observations.

Transports upstream by truck have been tested. They give good results only under specifc conditions. 
The duration of studies varied from 2 months to 8 months.

The accuracy of results is directly dependent on the number of personnel assigned to the study.

Use of radiotracking to survey or to design fishways appears to be a lumbersome but irreplaceable technique for the obtention of results concerning fish behaviour.

Résumé. - Plusieurs études de radiopistages ont été entreprises en France depuis 1985 sur trois espèces de poissons migrateurs : saumon atlantique (Salmo salar), truite de mer (Salmo trutta trutta), grande alose (Alosa alosa) dans le cadre de suivis relatifs à la construction de passes à poissons sur des barrages d'Electricité de France.

Trois sites ont fait l'objet d'études :

- Aménagement de Poutès-Monistrol sur l'Allier : détermination des possibilités d'accès du saumon jusqu'à l'ascenseur à poisson nouvellement installé au barrage; l'effet du débit turbiné à l'usine de Monistrol a été particulièrement étudié.

- Seuil de $S^{\prime}$-Laurent-des-eaux sur la Loire : détermination des caractéristiques d'un futur ouvrage de franchissement pour l'alose.

- Aménagement de Mauzac sur la Dordogne : détermination de l'attractivité pour l'alose et la truite de mer d'une nouvelle passe à poissons située à l'usine.

Nous avons utilisé du matériel de radiopistage américain (Advanced Telemetry System et Smith Root) avec des fréquences radio dans les gammes 40-41 Mhz et 48-49 Mhz. Les poissons ont été marqués avec divers types d'émetteurs implantés dans l'estomac. 28 aloses, 43 saumons et 18 truites de mer ont été marqués.

Diverses techniques de pistage ont été utilisées en fonction des caractéristiques de chaque site et des espèces de poissons concernées :

- pour le pistage manuel (à pied, à bord de voitures, bateaux et avions), divers types d'antennes ont été employés : antenne boucle, "adcock", fouet ou immergée. Les localisations précises ont été effectuées par biangulation ou triangulation ou à l'aide d'antennes immergées;

- pour les repérages automatiques, nous avons utilisé des enregistreurs graphiques. La durée des études a varié de 2 à 8 mois. Cet article s'attache plus à décrire les techniques utilisées que les résultats biologiques obtenus.

Il s'avère essentiellement que :
- la précision des résultats obtenus est, du fait de la lourdeur de la technique, très dépendante du potentiel humain intervenant sur le terrain,

- l'utilisation de la technique de radiopistage, quoique lourde d'utilisation et coûteuse, est irremplaçable pour l'obtention des données sur le comportement des poissons à l'approche des ouvrages de franchissement.

\section{INTRODUCTION}

The use of radio telemetry for studying fish behaviour Under natural conditions is a relatively new technique in France : an ultrasonic telemetry experience on pike (Esox lucius) and carp (Cyprinus carpio) as well as radio telemetry experiences were conducted in 1977 for studying fish movements in the warm discharge of a thermal power-station (Trocherie and Bercy, 1984).

The first uses of radio telemetry on migrating fish, salmon (Salmo salar) and shad (Alosa alosa) occured in 


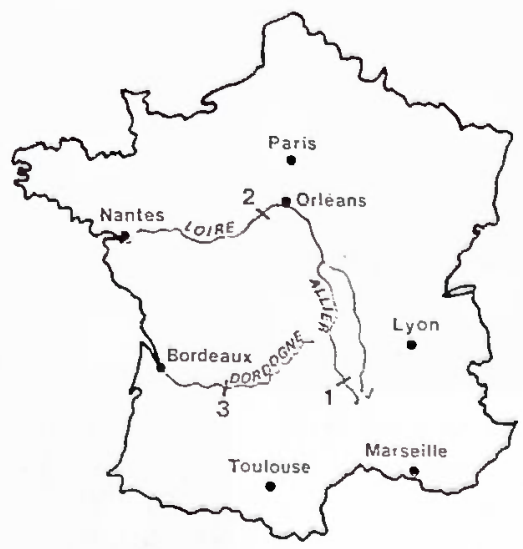

1 Poutes-Monistrol hydropower project on the Allier river

2 St Laurent-des-eaux weir on the Loire river

3 Mauzac hydraulic plant on the Dordogne river

Figure 1 : Location of the three areas investigated by radio telemetry

1982, on the Loire river (Baril and Gueneau, 1986; Steinbach et al., 1986).

Radio telemetry techniques were recently applied (1985 to 1987), to migrating fish (salmon, shad, sea-trout (Salmo trutta trutta)) when Electricity of France built new fishways on the main French rivers (Gregoire and Travade, 1980).

This paper emphasizes the radio telemetry techniques used at three different places in these fishways studies of 1986 and 1987 rather than the biological results.

We chose radio telemetry for its advantages compared to the ultrasonic telemetry system as reported by several authors (Stascko and Pincock, 1977; Mc Leave et al., 1978; Solomon, 1982) : several means of tracking are offered (use of above water antennas which can be located on a vehicle, boat or airplane as well as totally immersed antennas), and radio signals are barely affected by turbulent water or noise near dams and power stations. Moreover, the range of water conductivity in the concerned rivers (50 to $250 \mu \mathrm{s} / \mathrm{cm}$ ) allows suitable frequencies to be used.

Three migrating species were studied : the Atlantic salmon (Salmo salar), the sea-trout (Salmo trutta trutta) and the shad (Alosa alosa).

\section{LOCATION AND SIGNIFICANCE OF THE STUDIES. THE FACTS.}

Radio telemetry studies were carried out in three different areas (see table 1) : the hydropower project of Poutes - Monistrol on the Allier river, the weir of St Laurent-des-eaux on the Loire river, and the Mauzac dam on the Dordogne river.

\section{Poutes-Monistrol study on the Allier} river

Located about $900 \mathrm{~km}$ from the Atlantic Ocean, in the spawning area of the Atlantic salmon the hydropower project includes the Poutes dam 
Table 1 : Equipment for radio-tracking

\begin{tabular}{|c|c|c|c|}
\hline Tracking method & Receivor & Antenna & Recorder \\
\hline Manual & $\begin{array}{l}\text { A.T.S. Program } \\
\text { scan model } \\
\text {. SMITH ROOT RF } 40\end{array}$ & $\begin{array}{l}\text { Loop, whip, } \\
\text { submorsed loop }\end{array}$ & \\
\hline Goniometry & (Idom manual) & Loop, sdcock & \\
\hline Automatic & $\begin{array}{l}\text { A.T.S. Program } \\
\text { scan model } \\
\text {. SMITH ROOT SA } 40\end{array}$ & $\begin{array}{l}\text { Loop, whip, adcock, } \\
\text { yaggi, submersed wire }\end{array}$ & $\begin{array}{l}\text { Easterline Angus } \\
\text { with ATS scon model } \\
\text { SMITH ROOT } \\
\text { FLD } 10 \text { ER }\end{array}$ \\
\hline
\end{tabular}

(16 $\mathrm{m}$ high) which provides power through a gallery to the Monistrol plant, by-passing $10 \mathrm{~km}$ of the river (turbined flow : $28 \mathrm{~m}^{3} / \mathrm{s}$ ).

In 1985, an automatic fish lift was built on the Poutes dam. The Allier river, tributary of the Loire river, is characterized in this area by a mean to high fall ( 3 to $6 \%$ ), is 30 to $80 \mathrm{~m}$ wide, and is 1 to $3 \mathrm{~m}$ deep.

The water conductivity is weak : 60 to $90 \mu \mathrm{s} / \mathrm{cm}$.

The intention was to study the conditions of access of the Atlantic salmon to the fish lift and possible problems of circulation for these migratory fishes in the ten kilometers low flow regulated part of the river located between the powerhouse and the dam. The behaviour of the salmon has been particularly observed near the junction between the tailrace (28 $\mathrm{m}^{3} / \mathrm{s}$ ) and the regulated river $\left(0.5 \mathrm{~m}^{3} / \mathrm{s}\right)$.

The operations took place in 1986 and 1987 (table 1), lasting respectively 7.5 and 9.5 months. 46 salmon (size : 73 to $103 \mathrm{~cm}$, weight : 5 to
$10 \mathrm{~kg}$ ) were tagged at 20 and $60 \mathrm{~km}$ downstream from the plant. The movements of 43 of them have been monitored with portable receivers on their way between the tagging area and the plant, and with automatic receivers at the Monistrol powerhouse and the Poutes dam.

The St Laurent-des-eaux weir, on the Loire river

The weir, planned to maintain enough water to supply a nuclear power-station, is located on the medium part of the Loire river, at $330 \mathrm{~km}$ from its mouth.

The weir, $245 \mathrm{~m}$ long and $1.5 \mathrm{~m}$ high, constitutes an obstacle that the shad can barely pass with some river flows. The Loire river in this area has a low fall $(0.2 \%)$, is 250 to $400 \mathrm{~m}$ wide and has a depth of 1.5 to $3 \mathrm{~m}$. The water conductivity is around $200 \mu \mathrm{s} / \mathrm{cm}$.

The intention was to study how the shad managed to pass the weir and their behaviour downstream from the obstacle in order to pass it. The ex- 
perience took place in 1987 over a period of 2.5 months (see Table 2). Nineteen aloses were captured at $15 \mathrm{~km}$ downstream from the dam. Their precise movements near the obstacle were detected by goniometry (biangulation and triangulation) and presence of fish by automatic recorder (see Fig. 2).

Mauzac power-plant, on the Dordogne river

Located on the medium port of the Dordogne river (100 $\mathrm{km}$ from the sea) the dam supplies, through a $1 \mathrm{~km}$ canal, a six turbine powerhouse with a total flow of $380 \mathrm{~m}^{3} / \mathrm{s}$, under a fall of $6.5 \mathrm{~m}$. In 1986 a pool fishway of the vertical slots type was built at the powerhouse.

The Dordogne river in this area is characterized by a medium fall, is 100 to $250 \mathrm{~m}$ wide, and is 1 to $3 \mathrm{~m}$ deep.
The water conductivity varies from 150 to $250 \mu \mathrm{s} / \mathrm{cm}$.

The motivation for the study, conducted in 1987 (see Table 2) was to determine the efficiency of the fishway for shad and sea-trout, and to optimize its functioning subject to various turbines operations.

Nine shad and nine sea-trout were capured 15 to $30 \mathrm{~km}$ downstream from the plant; their behaviour was studied by goniometry in the tailrace, and in the fishway with automatic receivers located on fixed points (see Fig. 2).

\section{RADIO TRACKING EQUIPMENT}

We exclusively used American equipment : Advanced Telemetry Systems, Inc, and Smith Root.

Table 2 : Characteristics of transmitters used (Advanced Telemetry System)

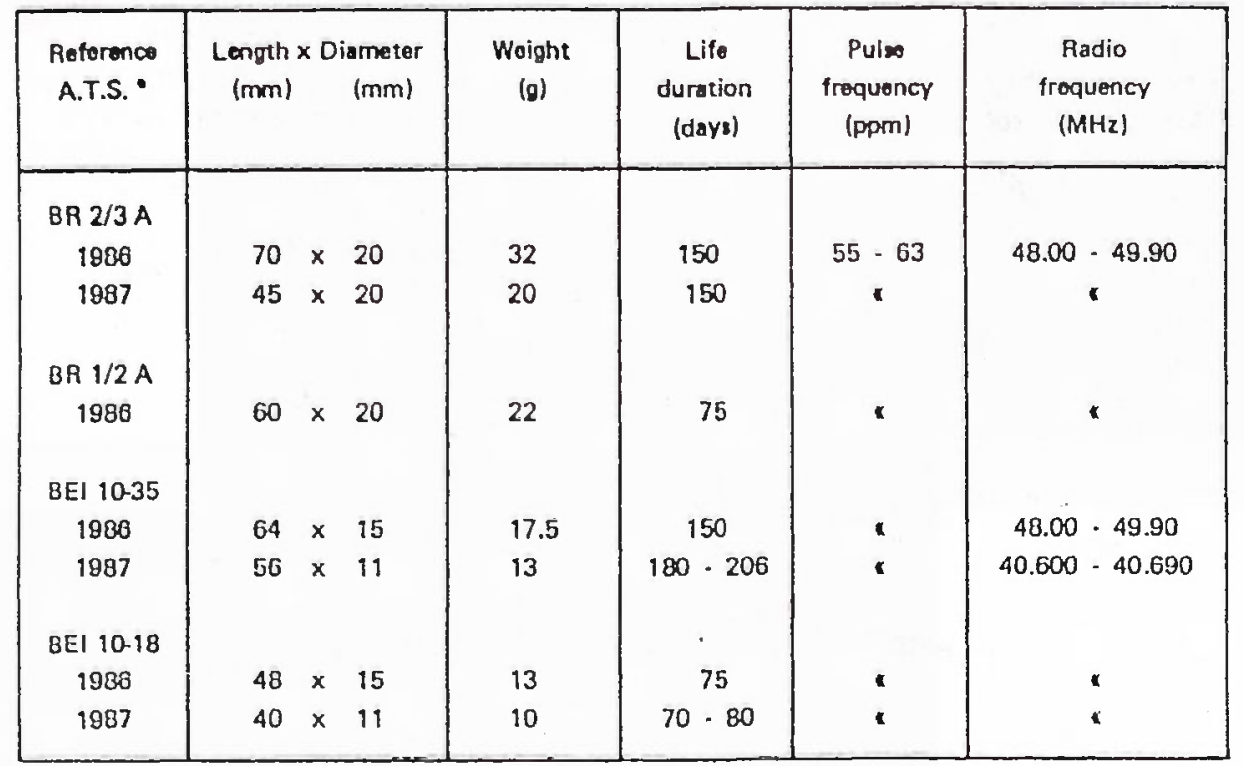

- Advanced Telemetry Systems, Inc. 


\section{SYMBOLS}

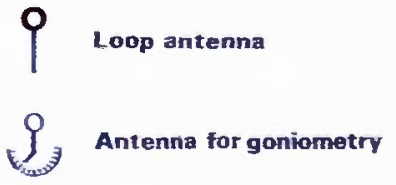

Underwater wire antenna

$\sum$ Automatic recording station

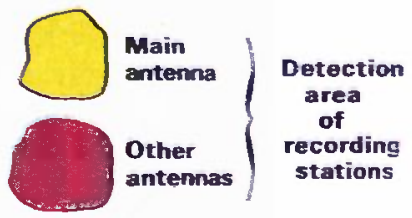

\section{SAINT LAURENT-DES-EAUX}

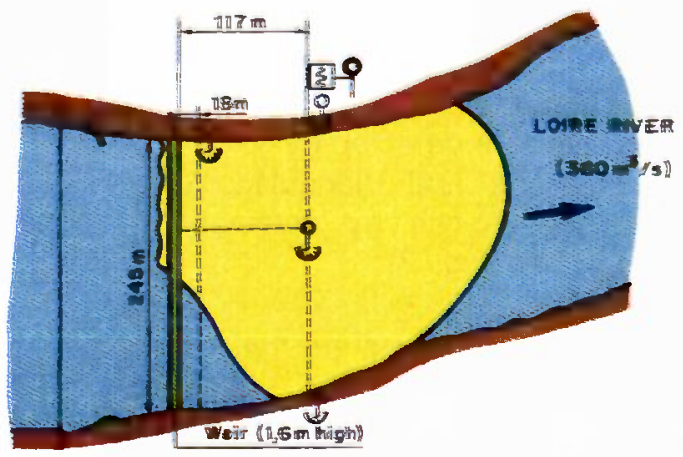

\section{POUTES- MONISTROL}

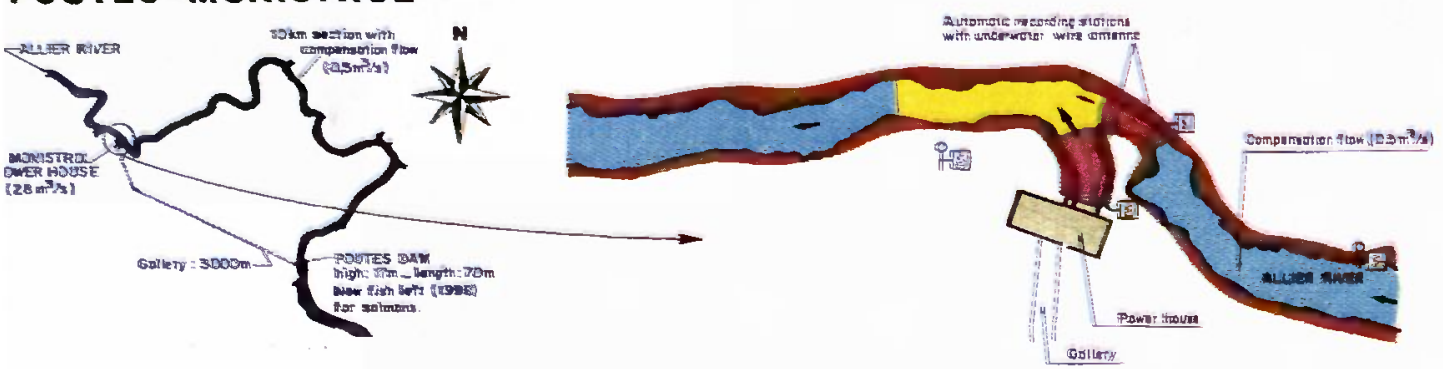

\section{MAUZAC}

6 turbines

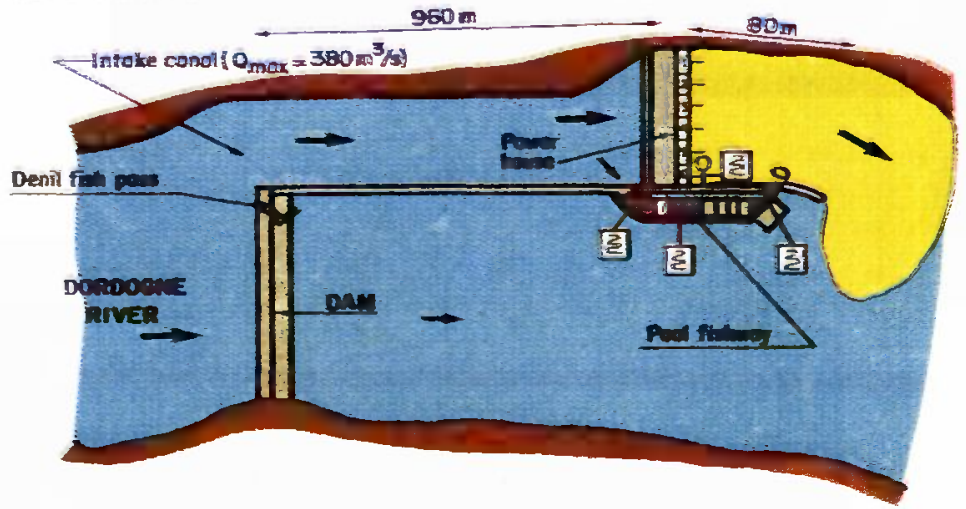

Fiaure 2 : Characteristics of radio tracking operations on the three sites 
Table 3 : Characteristics of radio tracking operations

\begin{tabular}{|c|c|c|c|c|}
\hline Study sites & $\begin{array}{c}\text { Study } \\
\text { duration dates }\end{array}$ & $\begin{array}{l}\text { Spocios } \\
\text { length - weight }\end{array}$ & $\begin{array}{l}\text { Number of } \\
\text { tagged fishes }\end{array}$ & $\begin{array}{l}\text { Tag type } \\
\text { (A.T.S.) }\end{array}$ \\
\hline \multirow{2}{*}{$\begin{array}{l}\text { POUTES. } \\
\text { MONISTROL }\end{array}$} & $\begin{array}{c}7.5 \text { months } \\
15 / 5 / 86-30 / 12 / 86\end{array}$ & $\begin{array}{l}\text { Atlantic salmon } \\
L=73 \cdot 103 \mathrm{~cm} \\
P=4.5-10 \mathrm{~kg}\end{array}$ & 26 & $\begin{array}{l}\text { BR } 2 / 3 \mathrm{~A} \\
\text { BR } 1 / 2 \mathrm{~A}\end{array}$ \\
\hline & $\begin{array}{c}3.5 \text { months } \\
16 / 3 / 87-30 / 12 / 87\end{array}$ & $\begin{array}{l}\text { Atlantic ealmon } \\
\mathrm{L}-77 \cdot 99 \mathrm{~cm} \\
\mathrm{P}=5 \cdot 9 \mathrm{~km}\end{array}$ & 19 & BR 2/3 A \\
\hline $\begin{array}{l}\text { St-LAURENT- } \\
\text { DES-EAUX }\end{array}$ & $\begin{array}{c}2.5 \text { months } \\
21 / 4 / 87 \cdot 2 / 7 / 87\end{array}$ & $\begin{array}{l}\text { Shod } \\
L \simeq 50 \mathrm{~cm} \\
P=2 \mathrm{~kg}\end{array}$ & 19 & $\begin{array}{l}\text { BEI } 10 / 18 \\
\text { BEI 10/35 }\end{array}$ \\
\hline \multirow{3}{*}{ MAUZAC } & 3 months & $\begin{array}{l}\text { Shad } \\
L=4.5 \cdot 55 \mathrm{~cm} \\
P=1.5 \cdot 2 \mathrm{~kg}\end{array}$ & 8 & BEI $10 / 18$ \\
\hline & $20 / 5 / 87-30 / 8 / 87$ & $\begin{array}{l}\text { Ses-trout } \\
L=46 \cdot 71 \mathrm{~cm} \\
P=1.2 \cdot 3.5 \mathrm{~kg}\end{array}$ & 8 & $\begin{array}{l}\text { BR } 2 / 3 \mathrm{~A} \\
\text { BR } 1 / 2 \mathrm{~A}\end{array}$ \\
\hline & $\begin{array}{c}2.5 \text { months } \\
29 / 10 / 87=16 / 12 / 87\end{array}$ & $\begin{array}{l}\text { Sos.trout } \\
L=52-81 \mathrm{~km} \\
P=1.3-4.8 \mathrm{~kg}\end{array}$ & 10 & $\begin{array}{l}\text { BR } 2 / 3 \mathrm{~A} \\
\text { BR } 1 / 2 \mathrm{~A}\end{array}$ \\
\hline
\end{tabular}

Two range of radio frequencies were used : 40.600 to $40.690 \mathrm{MHz}$ and 48.000 to $49.990 \mathrm{MHz}$. These low frequencies were chosen because they are free from use in France and because we had to work in medium conductivity waters, where the absorption of these radio frequencies is lower than for the higher frequencies which are for instance used in Great Britain (104.6-106.0 MHz reported by Beach and Storeton-West, 1982 or Solomon, 1982) or by several American authors (164 $\mathrm{MHz}$ by Weeks, reported by Mc Leave et al., 1978).

\section{The transmitters}

Several types of transmitter, with the A.T.S. label, were used. Their characteristics are reported in Ta- ble 2 : they were cylindrical, 40 to $70 \mathrm{~mm}$ long, their diameter was 11 to $20 \mathrm{~mm}$, their weight 10 to $20 \mathrm{~g}$ (in the air), with a battery life from 70 to 200 days. The components and the lithium battery were embedded in transparent resin. The external antenna was a flexible wire $30 \mathrm{~cm}$ long, trailed from one end of the transmitter. Each transmitter generated a pulsed radio signal at a different frequency, with a minimum of $10 \mathrm{KHz}$ increments.

\section{The receivers}

Three types of rechargeable battery-powered, portable receivers were used:

- Smith Root RF 40 manual model to choose the frequency $(40.000$ to $40.999 \mathrm{MHz}$ ). 
- Smith Root SR 40 with 10 programmed frequencies $(40.600$ to $40.690 \mathrm{MHz}$ ) and simultaneous detection.

- A.T.S. programmable scan-model, able to memorize a maximum of 2000 radio frequencies and automatic scanning. Each frequency (between $48.000 \mathrm{MHz}$ to $49.999 \mathrm{MHz}$ ) could be picked up.

\section{Automatic recorders}

Two different graphic recording systems were used :

- Smith Root FLD 10 ER, linked to the receiver SR 40 :

- able to receive 10 transmitters,

- autonomy : 1 week on $12 \mathrm{~V}$ battery,

- time precision on graph : 10 to $30 \mathrm{mn}$,

- Easterline Angus, linked to the scan-transmitter model ATS :

- able to receive 244 transmitters,

- autonomy : 7 to 14 days,

- time precision on graph : $1 \mathrm{mi}-$ nute.

\section{Antennas}

A wide range of antennas were used, depending on the tracking system selected.

- Above antennas :

- One fourth wavelength directional loop $40 \times 40 \mathrm{~cm}$

- Whip : $1.5 \mathrm{~m}$ long

- Adcock : $3 \times 2.3 \mathrm{~m}$

- Yagi

- A flexible wire varying from $1.60 \mathrm{~m}$ long $(\lambda / 4)$ to $6.30 \mathrm{~m}(\lambda)$.

- Underwater antennas :
- Small loop on a coaxial wire (12 to $20 \mathrm{~cm}$ ) as described by Solomon and Storeton-West in a 1983 report.

- Flexible wire of varying length according to the area to be covered

\section{FISH TAGGING}

Fishes were caught in a trap on a downstream fishway (Poutes and Mauzac) or by professional fishermen (St Laurent-des-eaux) at a minimum distance of $15 \mathrm{~km}$ downstream from the tracking area (see first paragraph).

The shads were captured by professional fishermen with a square-dipping net. It had no traumatic effect on the fish which were emerged only a few seconds and put immediatly in a tank.

\section{Tagging technique}

On the three species, the transmitters were inserted into the stomach, according to the method described by several authors (Mc Leave et al., 1968; Burger, 1981; Baril and Gueneau, 1986, Steinback et al., 1986, Solomon, 1982).

All the salmons and the sea-trouts were anesthetize before tagging. For the shads we tagged with (Mauzac) and without (St Laurent-des-eaux) anesthetic.

The transmitter, lubricated with glycerin, was inserted into a stiff plastic tube, and another tube was used to push the transmitter down the oesophagus into the fish's stomach. 
For the salmon and the sea-trout, the antennas were inserted behind the last gill arch and trailed alongside the fish.

For the shad, the antennas were stuck on the corner of the maxillaries and trailed back.

\section{Tagged-fish behaviour transmitters retention}

Generally speaking, all fish stayed from 1 to several hours in the release site. Nearly all the salmon and seatrout went upstream after this time (except fish in bad condition and those badly handled or transported : 2 out of 18 sea-trouts and 2 out of 45 salmons only). Systematically, (27 out of 28 cases), shads stepped down from $500 \mathrm{~m}$ to $20 \mathrm{~km}$ before going upstream again, after some hours to 10 days (Table 3 ).

The few tagged fish which remained in the release site without migra- ting again were those affected by illness or badly transported (shads : 4/18; salmons : 2 to 4/46; sea-trouts : 2 to $3 / 18$ ).

It is hard to compare the results obtained for the shad with and without anesthetic : their number was very small; the fish in Mauzac received the antenna at a higher water temperature $\left(17^{\circ} \mathrm{C}\right)$ than in St Laurent $\left(14^{\circ} \mathrm{C}\right)$. We may note that in Mauzac, 5 shad were tagged with dummy transmitters, transported and kept into a circular stream water tank for 5 months, without any mortality.

Transmitters regurgitation was low for the shad (1 to 5 ? $^{*} \quad / 28$ and nearly nonxistent for the salmon (1 or $\left.2 ?^{*} / 45\right)$. Concerning sea-trout, we noticed a systematic regurgitation of all the transmitters during the spring (June), 1 to 20 days after their insertion, as observed by Solomon (1982) in Great-Britain. On the contrary, no

Table 4 : Behaviour of fishes after radio tagging

\begin{tabular}{|c|c|c|c|c|c|}
\hline Site & Spocies & $\begin{array}{l}\text { Temporary } \\
\text { downstrosm } \\
\text { migrat. } \\
\text { (nit) }\end{array}$ & $\begin{array}{c}\text { Definitivo } \\
\text { downstraam } \\
\text { mg. } \\
\text { (nb) }\end{array}$ & $\begin{array}{c}\text { Rogurgitation } \\
\text { transmitter } \\
\text { (nb) }\end{array}$ & Mortalizy \\
\hline $\begin{array}{l}\text { POUTES } \\
\text { MONISTROL }\end{array}$ & Salmon & $5 / 45$ & $6 / 45$ & 27 ou doard & 1 to $2 ?$ \\
\hline $\begin{array}{l}\text { St-LAURENT- } \\
\text { DES-EAUX }\end{array}$ & Shad & $\begin{array}{c}18 / 19 \\
500 \mathrm{~m} \text { d } 11 \mathrm{~km}\end{array}$ & $0 / 19$ & $\begin{array}{c}1 \text { a } 2 \geq / 19 \\
T+3^{*}: T+22 ?\end{array}$ & $\begin{array}{c}0+1 ? / 18 \\
T+3 ?\end{array}$ \\
\hline \multirow{3}{*}{ MAUZAC } & Shad & $\begin{array}{c}5 / 9 \\
1 \mathrm{a} 7 \mathrm{~km}\end{array}$ & $3 / 8$ & $\begin{array}{c}0 \\
T+7 ? ; T+307, ?\end{array}$ & $\begin{array}{c}0 \bowtie 3 ? / 9 \\
T+7\} ; \\
T+30 ? ; ?\end{array}$ \\
\hline & $\begin{array}{l}\text { Sea-trout } \\
\text { tagged } \\
\text { june }\end{array}$ & $\begin{array}{c}0 / 8 \\
1 \& 7 \mathrm{~km}\end{array}$ & $2 / 8$ & $T+18 / 5$ & o \& $2 ? / 8$ \\
\hline & $\begin{array}{l}\text { Soa-trout } \\
\text { tagged } \\
\text { october }\end{array}$ & $1 / 10$ & $0 / 10$ & $\begin{array}{c}0 / 8 \\
\text { during } 27 \\
\text { to } 45 \text { days }\end{array}$ & od $17 / 9$ \\
\hline
\end{tabular}

- $T+x$ : Numbor of days after tagging.

- ? : regurgitation or mortality ? 
regurgitation was noticed in the autumn (October-November) on 8 fishes tagged for a period from 27 to 45 days (Table 3 ). This phenomenon probably results from the loss of stomach functions when the spawning season arrives.

All the fish on the three species who kept their transmitters and migrated upstream presented an apparently normal behaviour during up to 9 months for the salmon, 2.5 months for the shad and 1.5 month for the sea-trout. Several tagged salmon apparently spawned.

Nonetheless, in Poutes we noticed that all the radio-tagged salmon ( $\mathrm{nb}$ $=5$ ) avoided the fish-lift trap whereas non-tagged salmons didn't hesitate.These fish were tagged after being captured by a similar trap, so we wonder if they did not memorize the trap. Further experiments are to be realised to confirm this thesis.

\section{TRACKING METHOD}

The classical tracking methods as described by several authors were used Mc Leave et al., 1977, Solomon, 1982; Burger, 1981; Baril et Gueneau, 1986.

\section{Manual tracking}

This was achieved from a vehicle (antennas with a magnetic base were used), from a boat (an above water loop antenna and a small immersed loop antenna for precise location were used), from an airplane or a helicopter (a loop antenna was used inside in a wooden plane, and wire antennas $3 \mathrm{~m}$ long $(\lambda / 2)$ or whip antennas used outdoors), or detection was realised by foot (loop antenna).

Range of detection varied with the type of antenna used, the depth of immersion and the water conductivity. Adcock and Yagi antennas gave the best results. For loop antennas $(\lambda / 4)$, placed at $1.7 \mathrm{~m}$ hights, the distances recorded were the following ones:

\begin{tabular}{|c|c|c|c|c|c|}
\hline $\begin{array}{c}\text { Depth(m) } \\
\text { Conductivity } \\
\mu \mathrm{s} / \mathrm{cm})\end{array}$ & 0,5 & 1 & 7 & 8 & 13 \\
\hline $70-90$ & $1500+$ & $\begin{array}{r}1200 \\
1500\end{array}$ & 600 & 500 & 400 \\
\hline $150-250$ & 1000 & 500 & - & - & $20-30$ \\
\hline
\end{tabular}

Immersed antennas allowed detection of the tagged-fish $10 \mathrm{~m}$ around the antenna (small loop or wire antennas). A more precise localization (within a few centimeters) was allowed when considering the intensity of the signal received. This system was used to detect the regurgitated transmitters, within areas of 10 meters depth.

For tracking by air, the plane flew at about $250 \mathrm{~m}$ altitude and about $130-140 \mathrm{~km} / \mathrm{h}$. The signal was generally detected during 30 to 40 seconds, which allowed the simultaneous tracking of 5 or 6 fish with a scan-receiver programmed each 4 secondes (detection range was around 1000 to $1500 \mathrm{~m}$ ). The fish was located to within 100-200 m by noting on a map the first detection and loss of the signal, with the transmitter considered to be in the middle of the area. 


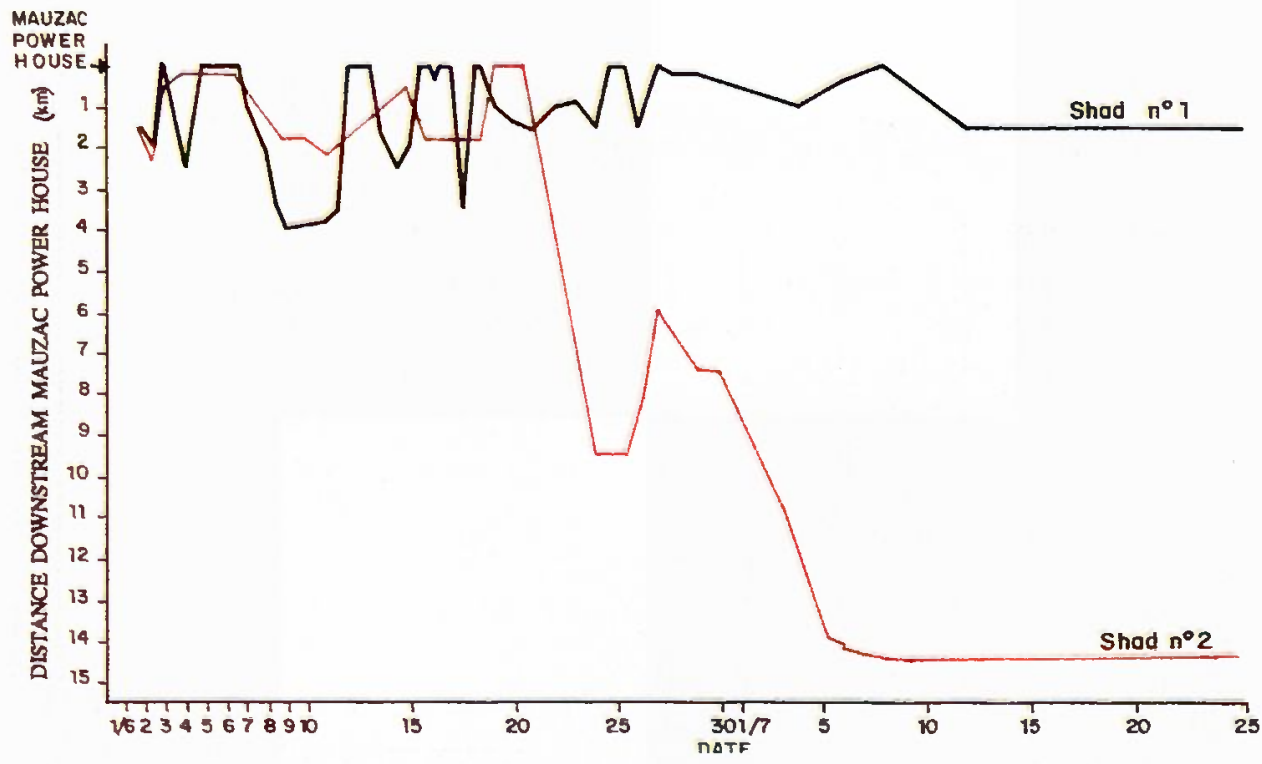

Figure 3 : Shad's movements under Mauzac powerhouse

\section{Location by goniometry}

The precise detection of fish near obstacles (St Laurent-des-eaux Mauzac) was realised with 2 or 3 loop antennas fixed on an axis equipped with a compass-card. The fish azimuth was determined by the double laterale extinction technique (bearing on the bisectrix of the 2 extinction axes : right and left). The 2 or 3 antennas were independantly used with note of azimuths and precise time (one point per minute) and the location of fish found crossing the azimuths after interpolation on the times measured. The observations stopped every 20 minutes, when the observer's vigilancy diminished.

With loop antennas, the angular precision was about $\pm 5^{\circ}$ without electrical noise in the radio signal, and $\pm 10^{\circ}$ with a bad signal.

\section{Automatic detection}

Passive listening stations (which recorded the passage of tagged fish past a fixed point) were used to precisely locate tagged fish in the fishways or in a not too large part of river near the obstacles (Allier near Monistrol powerhouse) (Fig. 2).

We used several receivers, each of them linked to an antenna for which the detection area was regularly calibrated. An assigned location of the antennas for covering areas permitted the precise location of the fish during their movements. Underwater wireantennas demonstrated the highest efficiency in this survey. According to their length and to the receiver gain chosen, they allowed the coverage of areas from 10 to $1000 \mathrm{~m}^{2}$. The optimum radius of these antennas was around $10 \mathrm{~m}$. This equipment $(2 \mathrm{im}$ - 


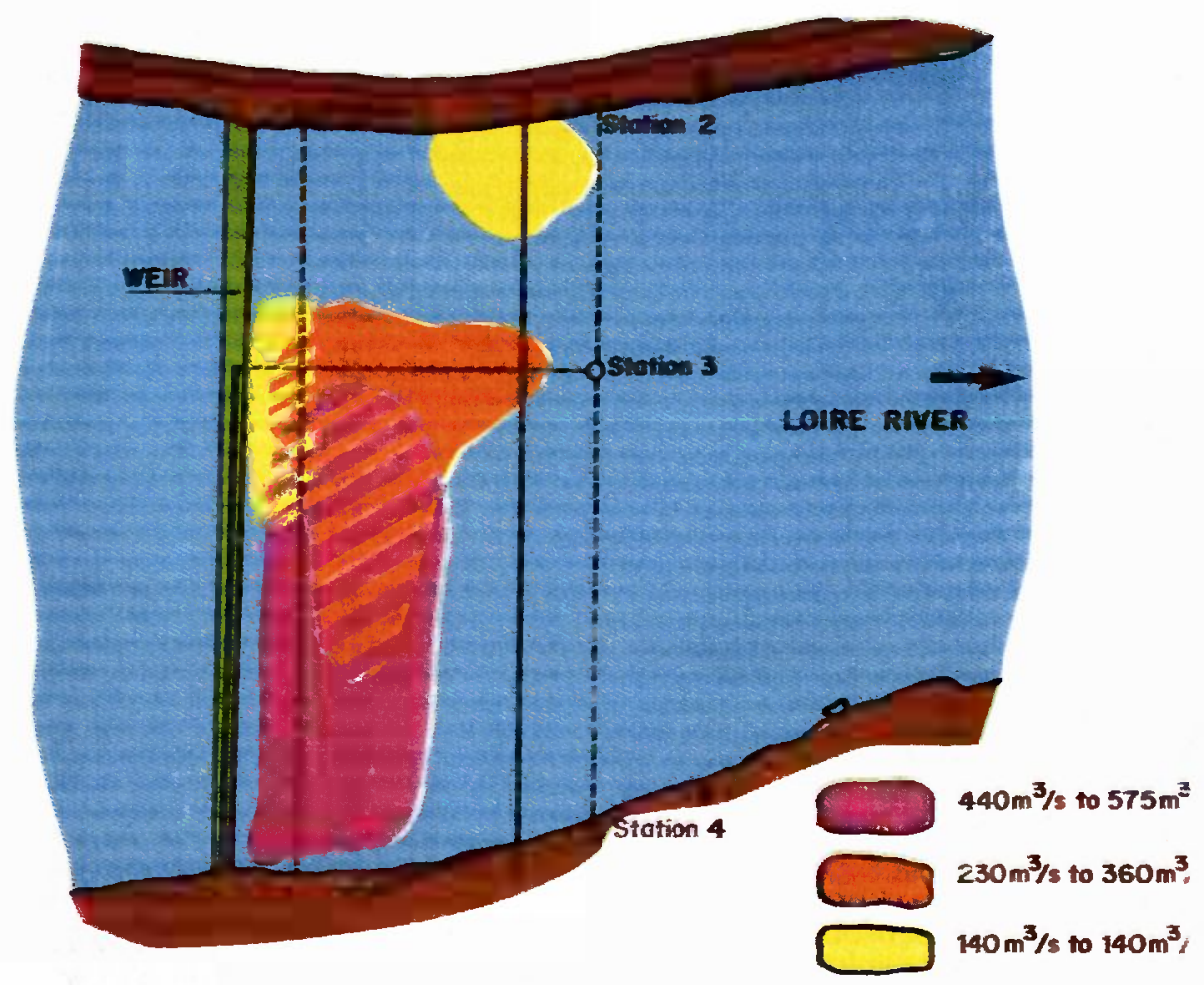

Figure 4 : Shads locations under $S^{\ell}$ Laurent weir for various river flow

mersed antennas and one aerial one) allowed the location of fish movements around the tailrace of Monistrol powerhouse to be followed automatically during several months.
The same equipment was used in Mauzac to determine the behaviour and the fish speed into the fishway: three underwater antennas were placed in pools respectively near the en-

Table 5 : Biological results

\begin{tabular}{l|l}
\multicolumn{1}{c|}{ Site } & \multicolumn{1}{c}{ Results } \\
\hline POUTES & $\begin{array}{l}\text { - description of salmon stopping in tailrace : effect of flow } \\
\text { and water temperature } \\
- \text { characteristics of releases to attrack fishes to the dam. }\end{array}$ \\
\hline SI-LAURENT & $\begin{array}{l}\text { - behaviour of shad in front of an obstruction } \\
- \text { range of river llows and temperature for passage upstream the weir } \\
- \text { location of fish under the weir according to river flow. }\end{array}$ \\
\hline MAUZAC & $\begin{array}{l}\text { - behaviour of shad and sea trout near turbine discharge } \\
- \text { delay to find fishway entrance, influence of fishway flow. }\end{array}$
\end{tabular}


trance, at the exit and in the middle part of the fishway.

\section{RESULTS}

The main results, we obtained by this method, not detailed in this paper, are reported in Table 5, Figure 3 and Figure 4.

\section{CONCLUSION}

The use of radio telemetry for field studies in three fishway surveys or on dams with projected fishway at E.D.F. was successfully employed on three fish species (43 salmon, 28 shad, 18 sea-trout).

The main information obtained resulting from the field application of the techniques are the following :

- the radio frequencies we employed (40-41 MHz and $48-49 \mathrm{MHz}$ ), gave good results. The range of detection, depending on fish depth and water conductivity (70 to $250 \mu \mathrm{s} / \mathrm{cm}$ ) was between 20 to $1500 \mathrm{~m}$,

- the insertion of radio tags in the stomach of the fish under anesthetic, with the weight of the tags in air varying between $0.2 \%$ and $1.4 \%$ of the weight of the fish, didn't affect the fish behaviour during one to two months for shad and sea-trout and up to seven months for salmon. For the shad we inserted radio tags with and without anesthetic, and didn't observe any differences between the two techniques. For the sea-trout we noti- ced the regurgitation of tags after one to twenty days in the spring, but no regurgitation in the autumn. However, we noticed that a minimum of stress and handling time were necessary during trapping and tagging to obtain this normal behaviour. On three salmon we noticed an abnormal behaviour near the trap of a fish lift : did they recall the trap from before tagging ? More results are necessary before any conclusions may be made

- the main tracking techniques were employed on each site so as to obtain the maximum of information about fish movements : manual tracking along the river bank by car, plane, boat, foot; precise location by goniometry; and automatic tracking by use of passive recording stations. On not too large rivers and in fishways, automatic recording with several above-water and underwater antennas gave good results in the realisation of continuous surveys of fish movements. Underwater wire antennas of various length gave better results than above water antennas for this use because the reception of the signal was more stable and less electric noises were present.

Generally speaking, this technique gave us better and quicker results than classical methods (sampling captures, external tagging...) in fishways studies. We concluded that many precise informations about fish behaviour according to fishways studies could only be obtained by radio telemetry. So we obtained irreplaceable results on salmon behaviour near tailraces according to the turbine flow, the season, and the water temperature, on their behaviour in a part of 
river with low flow and near the entrance of a fish lift. For the shad, we analysed the fish behaviour downstream from a dam according to the water temperature and river flow, and we determined the location of passage attempts.

This technique appeared to be heavy in terms of the price of equipment and tags (commercial prices of tags around $1000 \mathrm{FF}$ to $1500 \mathrm{FF}$ ), and in field personel. A minimum of two to three people was necessary on a large river to track several fish with no recording station, and one to two people with an automatic recording station. More people were necessary for trapping and tagging.

For these reasons, improvements on more accurate automatic recording systems would be a very useful development for the future.

\section{RÉFÉRENCES}

Baril D., Gueneau P., 1986 : Radiopistage de saumon adulte (Salmo salar) en Loire Bull. Fr. Disc., 302 : 86-105.

Beach Moh., Storeton-West T.J., 1982 : Design Considerations and Performance Checks on a Telemetry Tag System. Symp. zool. Soc. Lond., 49 : $31-45$

Burger C., Hepler K., Roth K., Delaney K., 1981 ; Radio Tracking of Adult Coho Solmon (Oncorhynchus kisutch) in the Deshka River Alaska. Proc. third Int. conf. on wildlife biotelemetry, Laramie, Wyoming : 15;-158.

Gregoire A., Travade F., 1987 : L'expérience d'EDF dans le domaine des passes à poissons : conception et suivi d'efficacité. La Houille Blanche, 1/2 : 65-71.

Mc Leave J.D., Power J.H., Rommel S.A., 1978 : Use of Radio Telemetry for studying upriver migration of adult Atlantic Salmon (Salmo salar) J. Fish Biol., 12 : 549-558.

Solomon D.J., 1982 : Tracking Fish with Radio Tags Symp. Zool. Soc. Lond., 49 : 95-105.

Solomon D.J., Storeton-West T.J., 1983 : Radio Tracking of migratory salmonids in rivers : development of an effective system. Ministry of Agriculture, Fisheries and Food, Fischeries Research Technical Report $n^{\circ} 75$.

Stasko A.B., Pincock D.G., 1977 : Review of underwater Biotelemetry, with emphasis on ultrasonic techniques $J$. Fish. Res. Board Can. 34 : 1261-1285.

Steinbach P., Gueneau P., Autuoro A., Broussard D., 1986 / Radiopistage de grande alose en Loire. Bull. fr. Pisc., 302 : 106-117.

Trocherie F., Bercy C., 1984 : Marquage du brochet (Esox lucius L.) et de la carpe (Cyprinus corpio L.) dans la Seine au niveau de Montereau à l'aide d'émetteurs ultrasonores. Cah. Lab. hydr. Montereau, $15:$ 13-19. 


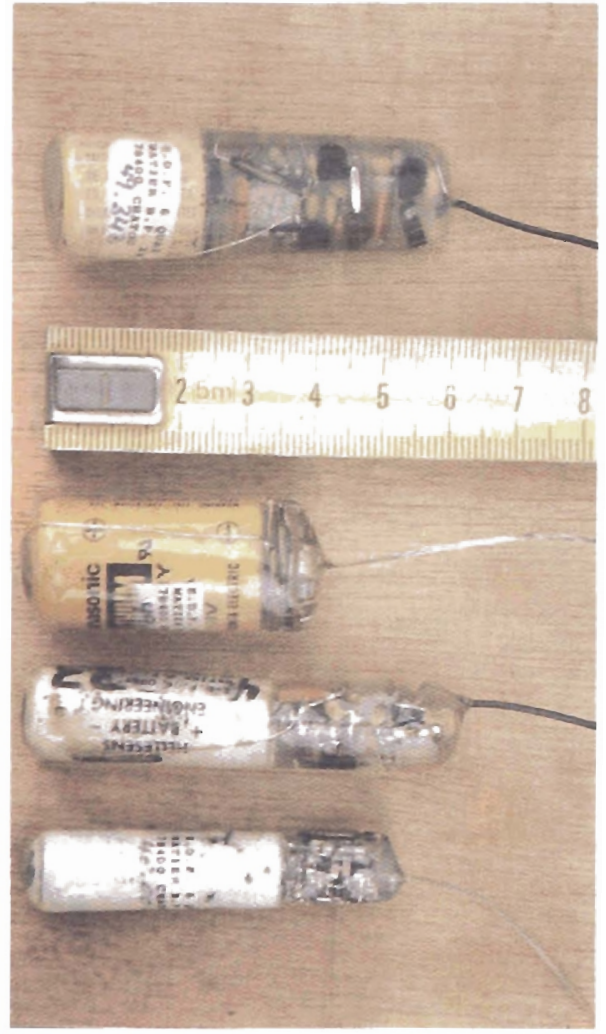

Various types of radio tags (A TS) 
F.Travade ef al.

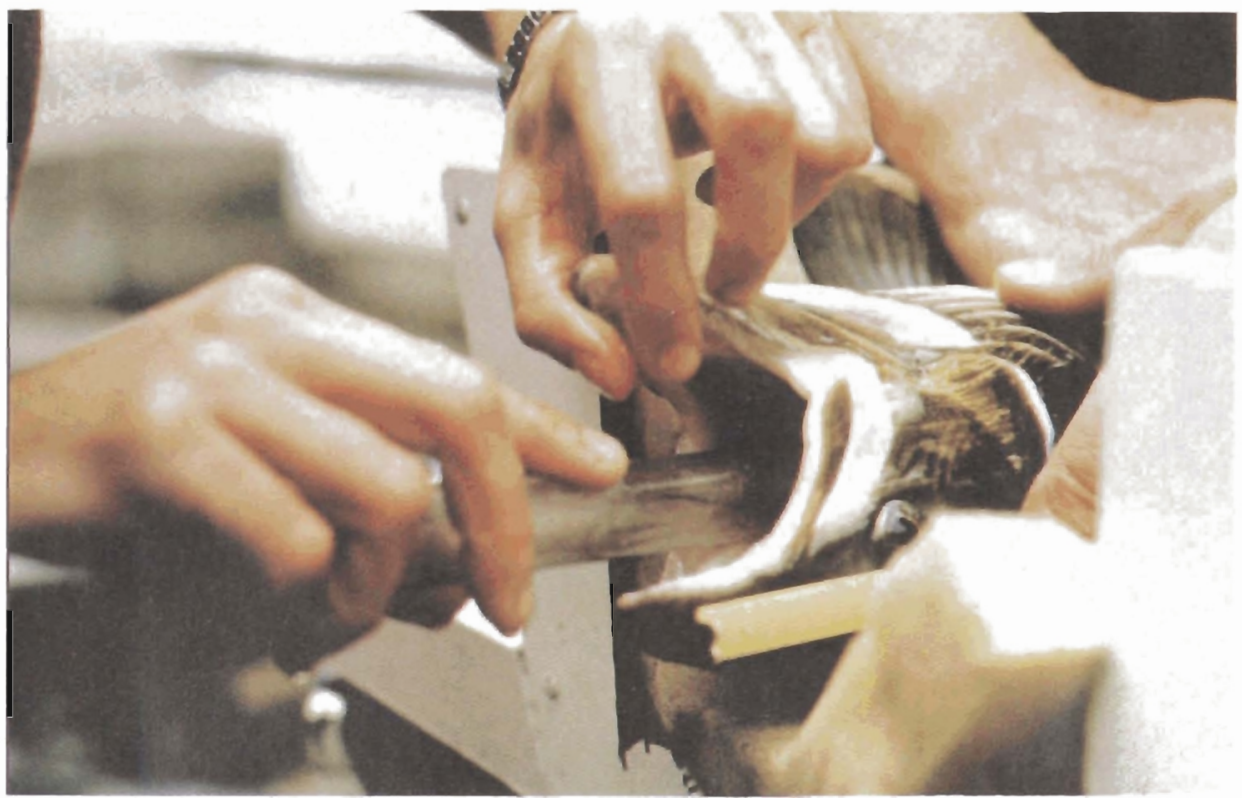

Salmon tagging (with anesthetic)

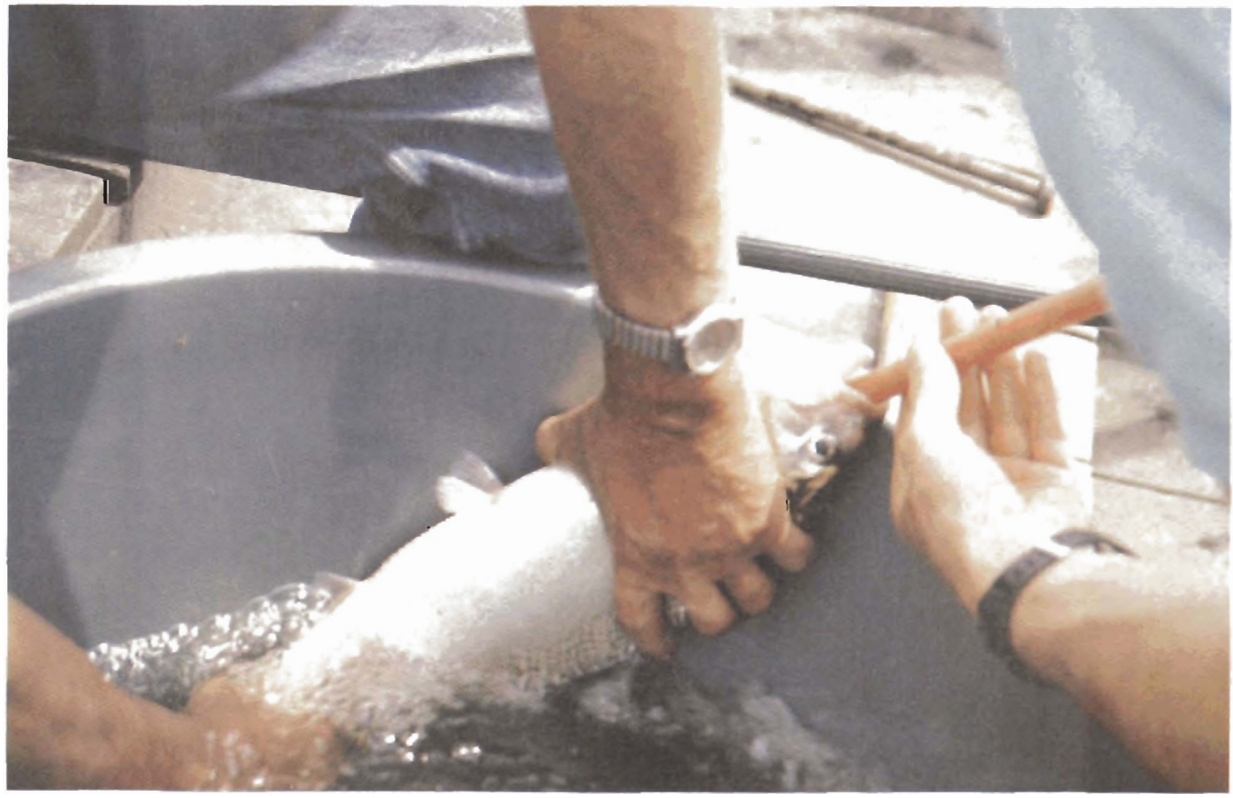

Shad tagging (without anestheric) 


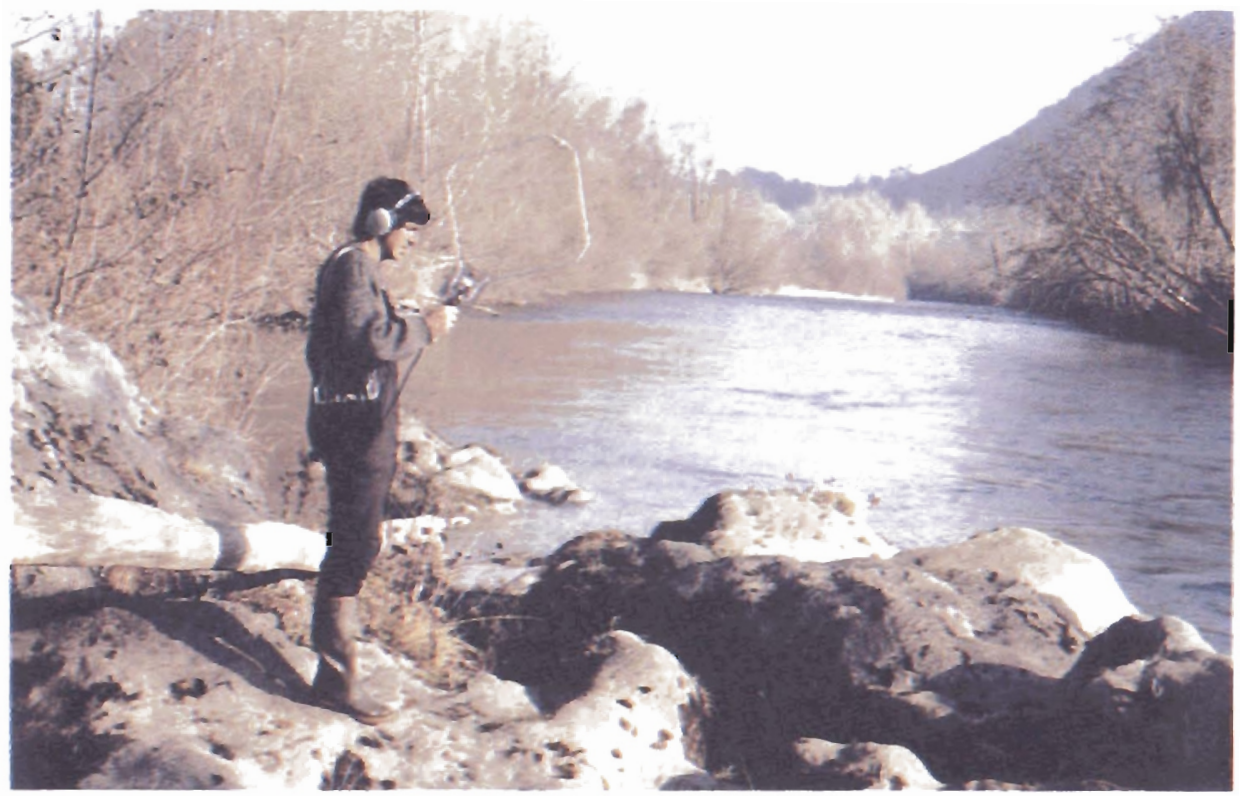

Location with a portable loop antenna

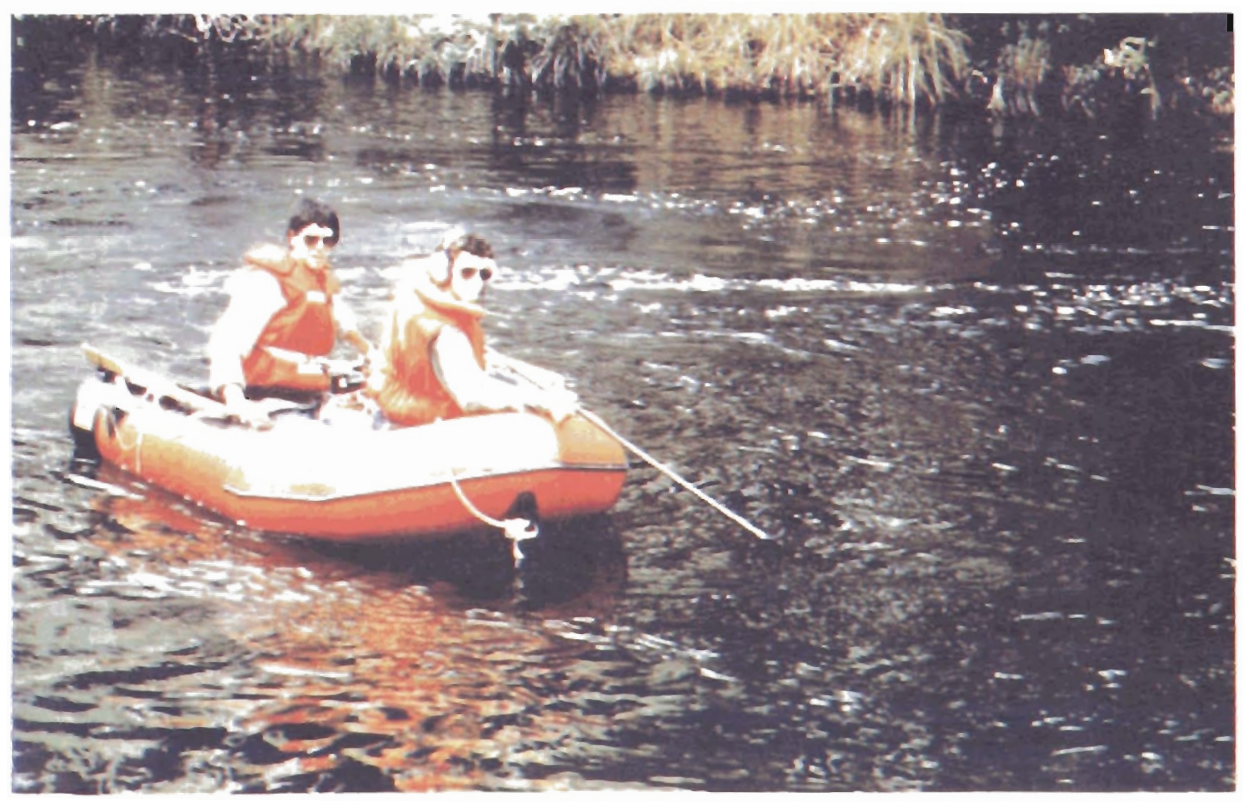

Precise location with an underwater minlature loop antenna 


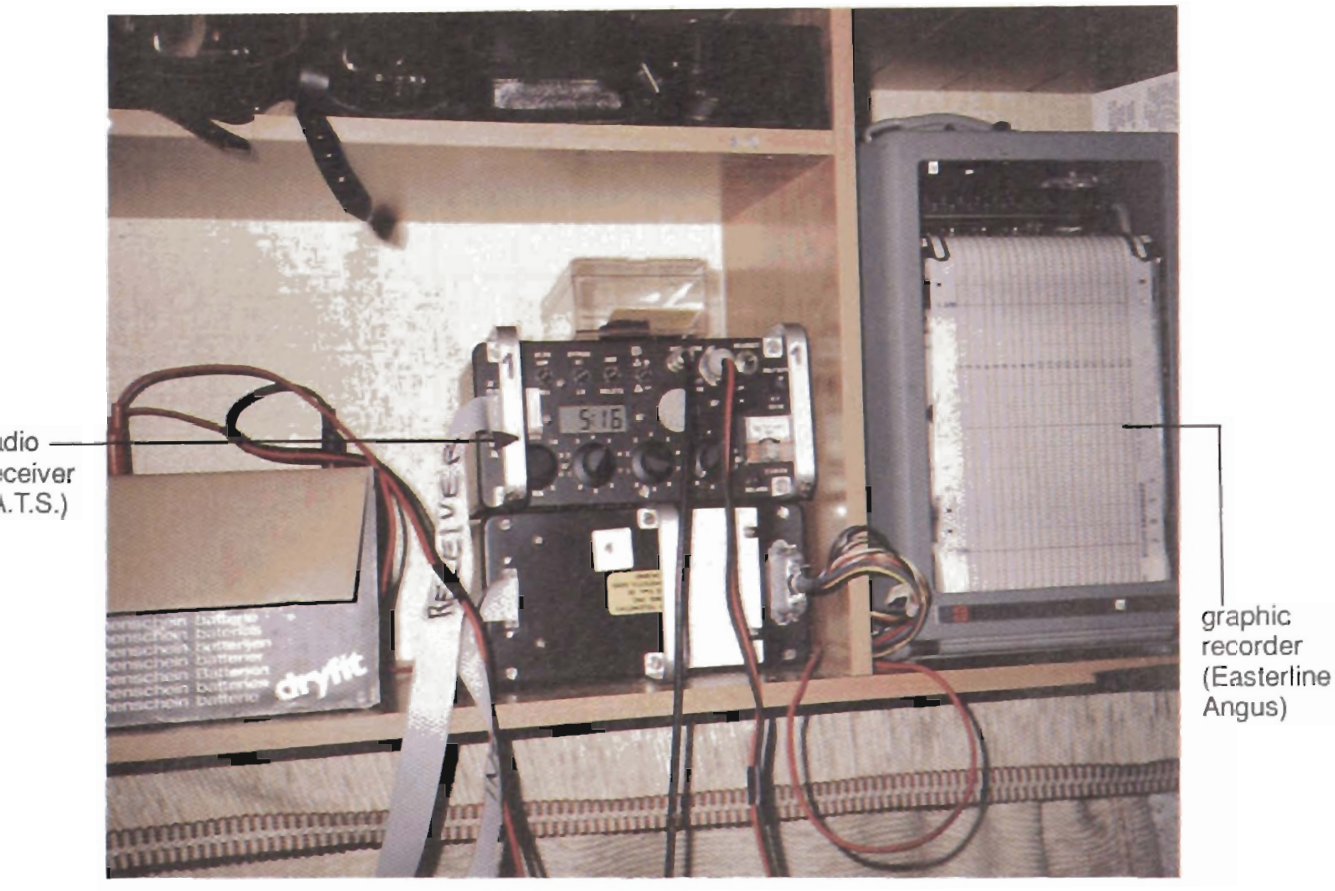

Automatic graphic recording station 